\title{
Extractable Nuclear Antigen Effect on the DNA Anti-DNA Reaction and NZB/NZW Mouse Nephritis
}

\author{
Alan D. Morris, Carol Littleton, Lourdes C. Corman, \\ JaMES Esterly, and Gordon C. Sharp \\ From the Division of Immunology and Rheumatology, Departments of \\ Medicine and Pathology, University of Missouri School of Medicine, \\ Columbia, Missouri 65201
}

\begin{abstract}
A B S T R A C T Extractable nuclear antigen (ENA) is composed of at least two components, one a ribonucleoprotein sensitive to ribonuclease or heat and the other a protein. Antibodies to ENA are associated with a relatively benign clinical course in patients with systemic lupus erythematosus (SLE) in which DNA antiDNA complexes are thought pathogenic. The effect of ENA and anti-ENA on DNA anti-DNA reactions in vitro was studied. ENA effectively inhibited an antiDNA hemagglutination reaction but no effect was found on binding of radioactive DNA or on the antihemocyanin hemagglutination reaction. The inhibitory effect was not abolished by yeast ribonuclease (RNase), heating, or DNase. Anti-ENA had no effect on antiDNA hemagglutination. In vivo, ENA altered the NZB/NZW mouse nephritis thought to be a model for human SLE nephritis. These results suggest the possibility of a role for ENA in alteration of diseases due to pathogenic DNA anti-DNA complexes.
\end{abstract}

\section{INTRODUCTION}

Extractable nuclear antigen (ENA) ${ }^{1}$ is a material extractable in isotonic buffers from mammalian cells. It contains antigens against which antibodies are directed that give a speckled fluorescent antinuclear antibody pattern. Crude ENA was previously shown to consist of approximately $26 \% \mathrm{RNA}$ and $70 \%$ protein (1).

Portions of this work were presented at the 35th Annual Meeting of the American Rheumatism Association, New York, June 1971, and at the 18th Interim Scientific Session of the American Rheumatism Association, Pittsburgh, $\mathrm{Pa}$., December 1972.

Received for publication 10 May 1974 and in revised form 30 December 1974.

${ }^{1}$ Abbreviations used in this paper: ENA, extractable nuclear antigen; MCTD, mixed connective tissue disease syndrome; NRS, normal rabbit serum in veronal buffer; RNase, yeast ribonuclease; RNP, ribonucleoprotein antigen; SLE, systemic lupus erythematosus; SRBC, sheep erythrocytes.
Several laboratories have recently shown that ENA consists of at least two separate antigens which have different properties $(1,2,3)$. Treatment of ENA with ribonuclease (RNase) or incubation at $56^{\circ} \mathrm{C}$ destroys the activity of one of these which is thought to be a ribonucleoprotein. Antibodies to this portion, which we have designated RNP antigen, are found in all patients with the mixed connective tissue disease syndrome (MCTD) and some with systemic lupus erythematosis (SLE). A second antigenic portion of ENA is not affected by RNase or incubation at $56^{\circ} \mathrm{C}$ and is thought to correspond to the previously described $\mathrm{Sm}$ antigen (1). SLE sera, containing antibodies to ENA, usually react with this portion and MCTD sera do not.

Patients with SLE appear to respond better to corticosteroids and have a more benign course with less severe renal disease if their sera contain antibodies to ENA (4). Patients with the MCTD syndrome, who manifest features of scleroderma, polymyositis, and SLE but rarely have renal disease, have high titers of hemagglutinating antibodies against ENA (2). These clinical observations suggest a possible protective role of ENA or antibodies to ENA.

Female NZB/NZW hybrid mice consistently develop several autoimmune phenomena and a lethal nephritis thought due in part to DNA anti-DNA complexes (5). Their disease is felt by many investigators to be an animal model analogous to human SLE.

We are studying the possible biologic roles of ENA and of antibodies to ENA. In the present studies we have investigated possible inhibitory activity by ENA and antibodies to ENA in DNA anti-DNA reactions in vitro. The possibility of in vivo activity of ENA has been explored using the NZB/NZW mouse nephritis model.

\section{METHODS}

ENA was prepared from fresh calf thymus nuclei as previously described $(2)$, and stored at $-70^{\circ} \mathrm{C}$. As anti-DNA, 
TABLE I

Effect of Anti-ENA on the Anti-DNA Hemagglutination System

\begin{tabular}{cccccc}
\hline $\begin{array}{c}1: 10 \\
\text { anti- } \\
\text { DNA }\end{array}$ & $\begin{array}{l}\text { Anti- } \\
\text { RNP* }\end{array}$ & $\begin{array}{c}\text { Anti- } \\
\text { Sm }\end{array}$ & $\begin{array}{c}\text { DNA- } \\
\text { coated } \\
\text { SRBC }\end{array}$ & $\begin{array}{c}\text { Uncoated } \\
\text { SRBC }\end{array}$ & Titer \\
\hline$m l$ & $m l$ & $m l$ & $m l$ & $m l$ & \\
0.25 & - & - & - & 0.25 & 0 \\
0.25 & - & - & 0.25 & - & 320 \\
0.25 & 0.1 & - & 0.25 & - & 320 \\
0.25 & - & 0.1 & 0.25 & - & 320 \\
\hline
\end{tabular}

Titers presented as reciprocal of highest dilution. Table presents findings of a single run but several anti-DNA sera produced identical results. Reagents were added in order listed.

* MCTD serum active against RNase-sensitive and heat-labile ENA.

$\ddagger$ SLE serum active against RNase-insensitive and heat-stable ENA.

sera were used which had been previously determined by hemagglutination and, in most cases, radioactive DNA binding to contain antibodies to double-stranded (native) DNA. For anti-ENA, sera were used which had been previously determined by hemagglutination to contain antibodies to ENA directed either against RNase-sensitive RNP or RNase-resistant (probably Sm) components of ENA and having no detectable anti-DNA activity. Antihemocyanin sera were prepared by immunization of a rabbit with the antigen in complete Freund's adjuvant.

To determine the effect of ENA or anti-ENA on antiDNA hemagglutination, native calf thymus DNA was prepared and the hemagglutination test for anti-DNA carried out as previously described (4). The test was modified by the addition of reagents indicated below and in Tables I and III. A 1:150 dilution of normal rabbit serum in veronal buffer at $\mathrm{pH} 7.4$ (NRS) was added in quantities necessary to keep final volumes equal. All tubes were incubated for $1 \mathrm{~h}$ at $37^{\circ} \mathrm{C}$ after addition of NRS, buffer, or reagents listed except for citrate which was added after incubation. In all cases, sheep red blood cells (SRBC) alone or coated with DNA were added last. ENA was added to the hemagglutination system as a $10-\mathrm{mg} / \mathrm{ml}$ solution in veronal buffer. Pancreatic DNase ${ }^{2}$ or yeast $\mathrm{RNase}^{2}$ was added as $0.1 \mathrm{ml}$ of a solution of $200 \mu \mathrm{g} / \mathrm{ml}$ in equal parts of 1:150 NRS and of phosphate buffer at $\mathrm{pH} 6.8$ and with $5 \mu \mathrm{mol} / \mathrm{ml} \mathrm{MgCl}_{2}$ added for DNase only. RNase solution was heat-treated for $5 \mathrm{~min}$ at $80^{\circ} \mathrm{C}$ to eliminate DNase activity. Where indicated, DNase was inactivated after the $1 \mathrm{~h}$ incubation by addition of $0.1 \mathrm{ml}$ of $0.01 \mathrm{M}$ sodium citrate. For both enzymes, $\mathrm{pH}$ during incubation was 6.83 . "Heated" ENA was added after incubation in solution at $56^{\circ} \mathrm{C}$ for $2 \mathrm{~h}$. Anti-ENA serum containing antibodies to RNP or Sm was added undiluted or in $1: 5$ dilution.

Quantitative DNA assay was done by the diphenylamine method (6). DNase activity was assayed by degradation of tritiated thymidine-labeled DNA into acid-soluble mononucleotides or oligonucleotides (7).

DNA binding by human sera was measured by a modification (see Table II) of the method previously described (8). ENA was added as $20 \mu \mathrm{l}$ of $50,10,1.0$, or $0.01 \mathrm{mg} / \mathrm{ml}$ concentration of ENA in tris buffer either before or after the usual incubation for $1 \mathrm{~h}$ at $37^{\circ} \mathrm{C}$. Binding of native DNA by mouse sera was tested in a similar manner except

Obtained from Worthington Biochemical Corp., Freehold, N. J. that labeled DNA was derived from cultured L1210 mouse leukemia cells.

To explore the in vivo effect of ENA, NZB/NZW hybrid mice were bred from stock colonies maintained by the Department of Laboratory Animal Medicine at the University of Missouri. 52 females were randomized into treatment and control groups at approximately $3 \frac{1}{2}$ mo of age from within individual litters. Treated animals were given weekly intraperitoneal injections of $1 \mathrm{mg}$ ENA in $0.25 \mathrm{ml}$ saline and controls received only saline. All mice were bled retroorbitally before the study, at monthly intervals, and terminally for determination of DNA-binding activity. Animals were sacrificed at 230,250 , or 270 days. Kidneys were examined by light microscopy after staining with hematoxylin and eosin or periodic acid Schiff and the disease quantitated by grading 40-60 individual glomeruli from 0 (no disease) to 4 on the basis of increasing cellularity and the appearance of neutrophils, necrosis, and sclerosis. Animals who had an average score of $0-2$ were considered to have mild disease and those with averages of $3-4$ as having severe disease. Direct immunofluorescence for glomerular gamma globulin was carried out by a modification of the method of Allansmith (9). Tissue was quick frozen in isopentane and liquid nitrogen, lyophilized, and embedded in paraffin. Percentages of diffuse and of focal glomerular staining were recorded from duplicate coded slides.

\section{RESULTS}

To determine whether antibodies to ENA could inhibit native DNA anti-DNA hemagglutination, three sera of known high titer hemagglutinating activity against RNP and two with activity against the Sm antigen were tested by addition to the DNA anti-DNA hemagglutination system (see Table I). Sera were added as $0.1-\mathrm{ml}$ solutions in NRS varying from undiluted to $1: 50$ dilution. In no case was the hemagglutinating titer of anti-DNA reduced by the addition of anti-ENA.

The effect of ENA on the radioactive DNA-binding assay for antinative DNA was studied as outlined in Table II. Sera of several different patients gave similar results. As shown, ENA caused no significant change in binding activity. If ENA was added after the incubation which is a normal part of our binding procedure, results were the same as those shown in Table II.

TABLE II

Effect of ENA on Binding of Radioactive DNA by Anti-DNA Serum

\begin{tabular}{|c|c|c|c|c|c|}
\hline KB DNA* & $\begin{array}{l}\text { Anti- } \\
\text { DNA }\end{array}$ & Albumin & $\begin{array}{c}\text { Tris } \\
\text { buffer }\end{array}$ & $\begin{array}{l}\mathrm{mg} / \mathrm{ml} \text { of } \\
\text { ENA in } \\
20 \mu \mathrm{l} \text { Tris } \\
\text { buffer }\end{array}$ & Binding \\
\hline$\mu l$ & $\mu l$ & $\mu l$ & $\mu l$ & & $\%$ \\
\hline 30 & - & 20 & 50 & - & 0 \\
\hline 30 & 20 & - & 50 & - & 66 \\
\hline 30 & 20 & - & 30 & 50.0 & 75 \\
\hline 30 & 20 & - & 30 & 10.0 & 62 \\
\hline 30 & 20 & - & 30 & 1.0 & 64 \\
\hline 30 & 20 & - & 30 & 0.01 & 72 \\
\hline
\end{tabular}

* From KB human epidermoid carcinoma cell lines labeled with tritiated thymidine $24 \mathrm{~h}$ before harvesting by the method of Marmur (11). 
TABLE III

Effect of ENA on the Anti-DNA Hemagglutination Reaction

\begin{tabular}{|c|c|c|c|c|c|c|c|c|c|c|}
\hline & $\begin{array}{c}1: 10 \\
\text { anti-DNA }\end{array}$ & $\begin{array}{c}\text { ENA } \\
10 \mathrm{mg} / \mathrm{ml}\end{array}$ & DNA & DNase & Citrate & RNase & $\begin{array}{c}\text { ENA* } \\
\text { heated }\end{array}$ & $\begin{array}{c}\text { SRBC } \\
\text { DNA } \\
\text { coated }\end{array}$ & $\begin{array}{c}\text { SRBC } \\
\text { uncoated }\end{array}$ & Titer \\
\hline & $m l$ & $m l$ & $m l$ & $m l$ & $m l$ & $m l$ & $m l$ & $m l$ & $m l$ & \\
\hline (a) & 0.25 & - & - & - & - & - & - & - & 0.25 & 0 \\
\hline (b) & 0.25 & - & - & - & - & - & - & 0.25 & - & 320 \\
\hline (c) & 0.25 & 0.1 & - & - & - & - & - & 0.25 & - & 10 \\
\hline (d) & 0.25 & 0.1 & - & 0.1 & 0.1 & - & - & 0.25 & - & 10 \\
\hline (e) & 0.25 & - & 一 & 0.1 & 0.1 & - & 一 & 0.25 & - & 160 \\
\hline (f) & 0.25 & - & - & 0.1 & - & - & - & 0.25 & - & 20 \\
\hline (g) & 0.25 & - & - & 一 & 0.1 & - & - & 0.25 & - & 320 \\
\hline (h) & 0.25 & 0.1 & - & - & - & 0.1 & - & 0.25 & - & 10 \\
\hline (i) & 0.25 & - & - & - & - & 0.1 & - & 0.25 & - & 320 \\
\hline (j) & 0.25 & - & - & - & - & - & 0.1 & 0.25 & - & 20 \\
\hline (k) & 0.25 & - & 0.1 & - & - & - & - & 0.25 & - & 10 \\
\hline (l) & 0.25 & - & 0.1 & 0.1 & 0.1 & - & - & 0.25 & - & 160 \\
\hline
\end{tabular}

Titers presented as reciprocal of highest dilution showing ${ }^{++}$agglutination on the Stavitsky scale (15). Table presents finding with a single anti-DNA serum but similar results were obtained with other anti-DNA sera which were sometimes of lower titer. Reagents were added in order listed. Volumes in tubes were kept equal by addition of appropriate amounts of buffer.

${ }^{*}$ ENA incubated for $2 \mathrm{~h}$ at $56^{\circ} \mathrm{C}$.

The effect of ENA on the hemagglutination reaction of antinative DNA was studied by the addition of $1 \mathrm{mg}$ of ENA to each serial dilution of the anti-DNA serum. Table III (lines $a-c$ ) presents our finding that ENA clearly inhibits the reaction. Earlier studies had shown that the use of smaller amounts of ENA produced a significant but smaller reduction in titer.

Because of the theoretic possibility that trace contaminants of DNA might inhibit the anti-DNA hemagglutination reaction, we tested the effect of pretreating the ENA with DNase. The results of that procedure and appropriate controls are presented in lines $d$ through $g$ of Table III. DNase failed to prevent inhibition of anti-DNA by ENA when the DNase was subsequently

TABLE IV

Degradation of Radioactively Labeled DNA to Acid-Soluble Mononucleotides or Oligonucleotides by DNase in Presence of ENA

\begin{tabular}{|c|c|c|c|c|c|}
\hline \multirow[b]{2}{*}{$\begin{array}{c}\text { DNase } \\
(2 \mu \mathrm{g} / \mathrm{ml})\end{array}$} & \multirow{2}{*}{$\begin{array}{c}\text { DNA } \\
(48.1 \\
\mu \mathrm{g} / \mathrm{ml})\end{array}$} & \multirow[b]{2}{*}{ ENA } & \multicolumn{2}{|c|}{ Total counts } & \multirow[b]{2}{*}{$\begin{array}{l}\text { Counts } \\
\text { released* }\end{array}$} \\
\hline & & & $\begin{array}{c}\text { Before } \\
\text { incubation }\end{array}$ & $\begin{array}{c}\text { After } \\
\text { incubation }\end{array}$ & \\
\hline$\mu l$ & $\mu l$ & $m g$ & & & $\%$ \\
\hline - & 50 & - & 150,948 & 759 & 0.6 \\
\hline 50 & 50 & - & 147,466 & 112,050 & 76.0 \\
\hline 50 & 50 & 0.01 & 151,635 & 125,299 & 82.7 \\
\hline 50 & 50 & 0.1 & 133,892 & 118,054 & 88.2 \\
\hline 50 & 50 & 1.0 & 138,146 & 111,964 & 82.1 \\
\hline 50 & 50 & 2.0 & 164,753 & 124,177 & 75.4 \\
\hline- & 50 & 1.0 & 161,783 & 1,057 & 0.7 \\
\hline
\end{tabular}

Volume was kept equal in all tubes by addition of appropriate volumes of buffer.

* Represents mean of paired samples. inactivated by citrate. Evidence for activity of DNase in our system is shown in Table III (lines $k$ and $l$ ). DNase effectively destroyed the ability of DNA itself to inhibit the DNA anti-DNA hemagglutination reaction thereby suggesting that the enzyme is capable, under these conditions, of digesting the DNA into fragments which are not inhibitory in this antigen-antibody system. The possibility that ENA contains inhibitors of DNase was also explored. It was necessary to use a separate assay since, in our hemagglutination system, a possible inhibitory effect by undegraded DNA couldn't be separated from the inhibitory effect of ENA. Our findings are shown in Table IV. The presence of ENA did not alter the ability of DNase to degrade DNA into acid-soluble mononucleotides or oligonucleotides. As additional evidence that the inhibitory effect of ENA was not due to DNA contamination, we measured the amount of DNA in our ENA by the diphenylamine test and found it to be $<0.03 \%$. Then, using a dose-response curve as previously described (10) for inhibition of DNA hemagglutination, we found that

TABLE V

Renal Histology at 250 Days in NZB/NZW Females Given ENA or Saline

\begin{tabular}{lcc}
\hline Degree of disease*..... Severe & Mild \\
\hline Control & 8 & 3 \\
ENA treated & 0 & 10 \\
\hline
\end{tabular}

$P<0.001$ (one tail test using Fisher exact test).

* Histologic scores of 0-2 were interpreted as mild disease and 3-4 as severe disease. 
the small quantities of DNA which could be present in our ENA did not inhibit the DNA antinative DNA hemagglutination reaction. It seems unlikely that DNA contaminants play a role in the inhibitory activity of ENA in view of these findings and of our observation that ENA failed to inhibit the DNA-binding system.

Since the RNP component of ENA loses its antigenic activity when exposed to RNase or heat, we studied the effects of these treatments on the ENA used to inhibit the anti-DNA hemagglutination reaction as seen in Table III (lines $h-j$ ). No significant loss of inhibitory activity occurred with either RNase or heat treatment of the ENA. RNase alone did not reduce the titer.

To explore the effect of ENA on a completed DNA anti-DNA reaction, a DNA anti-DNA hemagglutination reaction set up in duplicate was allowed to proceed to completion. After withdrawing $0.25 \mathrm{ml}$ of fluid from each tube, $0.25 \mathrm{ml}$ of $\mathrm{NRS}$ containing $1 \mathrm{mg}$ ENA was added to one row of tubes and $0.25 \mathrm{ml}$ of NRS without ENA was added to the other row. The agglutinated cells were resuspended and allowed to settle. Tubes without ENA showed the previous agglutination pattern whereas the cells in the tubes to which ENA was added settled as buttons, indicating a negative reaction. To show that the effect of ENA was not a nonspecific effect on the hemagglutination reaction, $1 \mathrm{mg}$ of ENA was added to each dilution in a rabbit antihemocyanin hemagglutination test. There was no change in the $1: 1,280$ titer of this reaction.

Table $\mathrm{V}$ presents the results of ENA administration in vivo in the NZB/NZW mouse model. Severity of disease increased with age in both groups. Younger animals sacrificed at 230 days showed mainly mild disease and no difference between the ENA-treated and control groups. Older mice, aged 270 days had advanced disease but comprised too small a group for a meaningful statistical analysis. At 250 days of age, however, 8 of 11 animals in the untreated control group had severe disease by light microscopy whereas none of the 10 ENA-treated mice had severe disease $(P<0.001)$. The percentage of glomeruli showing diffuse gamma globulin deposition, measured by the direct immunofluorescence technique, correlated well with the degree of histologic disease in both control and ENA-treated animals (Spearman rank correlation coefficient $=0.70, \quad P<$ 0.01 ). $50-95 \%$ of glomeruli from all untreated controls at 250 days stained diffusely. Focal glomerular staining was commonly associated with mild or no disease by light microscopy.

\section{DISCUSSION}

Our results indicate that ENA effectively inhibits the DNA anti-DNA hemagglutination reaction. The fact that no effect was observed on the binding of radioisotope-labeled DNA suggests that ENA does not prevent the recognition by anti-DNA of antigenic determinants of DNA or the direct antigen-antibody combination necessary for binding. The inhibition we have demonstrated could result from a change in the spatial or charge configuration of the antigen and the DNA antiDNA complexes. Since the complex size is known to influence the pathogenicity of antigen-antibody complexes (12), it is possible that ENA influences disease by changing the size or some other characteristic of antigen-antibody complexes in vivo. This possibility is supported by the finding of Hamburger, Friedlander, and Barland (13) that crude ENA itself forms complexes with DNA on red cells in vitro.

Whereas physical changes in antigen-antibody complexes might, in themselves, diminish glomerular deposition and decrease disease, it is also conceivable that ENA impedes the fixation of complement in disease states. Work to date in our laboratory has shown that ENA in low concentrations does not impair the fixation of complement by anti-DNA antibodies but ENA in higher concentrations similar to those used in our inhibition studies is anticomplementary in itself.

The fact that ENA has no influence on the hemagglutination reaction against hemocyanin makes it unlikely that a nonspecific effect on the hemagglutination reaction itself is involved and it also seems unlikely, in view of the sequence of events in our test and the observations by Hamburger et al. (13) that ENA significantly interferes with adherence of DNA to the tanned cells.

Our data suggest that it is an RNase and heat-insensitive material which interferes with the DNA anti-DNA reaction. It is, therefore, a reasonable possibility that the interference is mediated by Sm antigen, but it could also be due to a currently unidentified component of ENA or an RNase and heat-resistant part of the RNP portion of ENA. It has been suggested (2) that antibodies to ENA could themselves exert a protective effect in patients with SLE or MCTD. Our finding that anti-ENA has no effect in vitro fails to support this possibility.

The significance of these observations for patients and/or healthy persons is currently unclear. Our preliminary observations of the effect of ENA in the NZB/ NZW mouse nephritis, which is thought due to DNA anti-DNA complexes (5), raises the possibility of a similar protective effect by ENA or one of its components in humans. We are currently working to enlarge and extend these observations on the effect of ENA in the mouse model. Since serum from normal humans contains DNA-binding materials which are apparently not antibodies (14), it is even conceivable 
that ENA or a similar material is present and is able to modify the physical state or consequences of any DNA which might be released into the circulation.

\section{ACKNOWLEDGMENTS}

The authors thank Dr. Patrick Henry for his generous donation of labeled K-B and L1210 mouse DNA and for technical advice. We are indebted to Miss Patre Mierzwa, Mrs. Chris Caputo, Miss Meredith Stander, and Miss Cynthia Evers for technical assistance.

This investigation was supported by U. S. Public Health Service grant Am-16141.

\section{REFERENCES}

1. Northway, J. D., and E. M. Tan. 1972. Differentiations of antinuclear antibodies giving speckled staining patterns in immunofluorescence. Clin. Immunol. Immunopathol. $1:$ 140-154.

2. Sharp, G. C., W. S. Irvin, E. M. Tan, R. G. Gould, and H. R. Holman. 1972. Mixed connective tissue disease-An apparently distinct rheumatic disease syndrome associated with a specific antibody to an extractable nuclear antigen (ENA). Am. J. Med. 52: 148-159.

3. Reichlin, M., and M. Mattioli. 1972. Correlation of a precipitin reaction to RNAprotein antigen and a low prevalence of nephritis in patients with systemic lupus erythematosus. N. Engl. J. Med. 286: 908-911.

4. Sharp, G. C., W. S. Irvin, R. L. LaRoque, C. Velez, V. Daly, A. D. Kaiser, and H. R. Holman. 1971. Association of autoantibodies to different nuclear antigens with clinical patterns of rheumatic disease and responsiveness to therapy. J. Clin. Invest. 50: 350-359.

5. Lambert, P. H., and F. J. Dixon. 1967. Pathogenesis of the glomerulonephritis of NZB/W mice. J. Exp. Med. 127 : $507-521$.
6. Burton, K. 1956. A study of the conditions and mechanism of the diphenylamine reaction for the colorimetric estimation of deoxyribonucleic acid. Biochem. J. 62: 315-323.

7. Colowick, S. P., and N. O. Kaplan. 1974. Nucleic acids and protein synthesis. Part E. Methods Enzymol. 29: 448.

8. Hahn, B. H., G. C. Sharp, W. S. Irvin, O. S. Kantor, C. A. Gardner, M. K. Bagby, H. M. Perry, and C. K. Osterland. 1972. Immune responses to hydralazine and nuclear antigens in hydralazine-induced lupus erythematosus. Ann. Intern. Med. 76: 365-374.

9. Allansmith, M., M. Goihman-Yahr, and D. N. Buell. 1964. Demonstration of gamma-2 globulin in human skin. J. Allergy. 35 : 313-321.

10. Koffler, D., V. Agnello, R. Winchester, and H. G. Kunkel. 1973. The occurrence of single-stranded DNA in the serum of patients with systemic lupus erythematosus and other diseases. J. Clin. Invest. 52: 198-204.

11. Marmur, J. 1961. A procedure for the isolation of deoxyribonucleic acid from micro-organisms. J. Mol. Biol. 3 : 208-218.

12. Germuth, F. G., Jr., L. B. Senterfit, and G. R. Dreesman. 1972. Immune complex disease. V. The nature of the circulating complexes associated with glomerular alterations in the chronic BSA-rabbit system. Johns Hopkins Med. J. 130: 344-357.

13. Hamburger, M., L. Friedlander, and P. Barland. 1974. Interactions of extractable nuclear antigen (ENA) and double stranded DNA. Arthritis Rheum. 17: 469-475.

14. Pincus, T. 1971. Immunochemical conditions affecting the measurement of DNA antibodies using ammonium sulfate precipitation. Arthritis Rheum. 14: 623-630.

15. Stavitsky, A. B. 1954. Micromethods for the study of proteins and antibodies. I. Procedure and general applications of hemagglutination and hemagglutinationinhibition reactions with tannic acid and protein-treated red blood cells. J. Immunol. 72 : 360-367. 